\title{
Effects of seasonal upwelling on hydrography and mesozooplankton communities in a Pacific tropical cove off Colombia
}

\author{
Bellineth Valencia, Alan Giraldo, Marisol Rivera-Gómez, Vanessa Izquierdo-Peña \\ \& Andrés Cuellar-Chacón \\ Grupo de Investigación en Ciencias Oceanográficas, Universidad del Valle. Cali, Colombia; bellineth.valencia@corre- \\ ounivalle.edu.co, alan.giraldo@correounivalle.edu.co,marisol.rivera.gomez@correounivalle.edu.co,vaneizqpe@ \\ gmail.com, andres.cuellar.chacon@correounivalle.edu.co
}

\section{Received 05-XII-2018. C Corrected 06-V-2019. Accepted 23-VII-2019.}

\begin{abstract}
Introduction: The effects of seasonal upwelling on the conditions of the water column and mesozooplankton communities are poorly understood in the coastal zones of the Eastern Tropical Pacific (ETP), despite the important role of upwelling events in the modulation of productivity in these zones. Objective: To evaluate the influence of seasonal upwelling over the Panama Bight on the structure of the water column and mesozooplankton communities in a tropical cove of the ETP. Methods: Hydrographic data and mesozooplankton samples were collected during four field campaigns in Ensenada de Utría (December 2011, February 2012, October 2013, and February 2013), an estuary located in the Northern Pacific coast of Colombia. Non-parametric and multivariate analyses were used to evaluate seasonal differences in the environmental and biotic variables. Results: Surface waters were warm $\left(>25^{\circ} \mathrm{C}\right)$ and presented low salinities $(<30)$ throughout the study period. In contrast, subsurface waters were colder $\left(<20^{\circ} \mathrm{C}\right)$, saltier $(>33)$, and presented low dissolved oxygen concentrations $\left(<2.0 \mathrm{ml} \mathrm{l}^{-1}\right)$ during the dry season (January - March), whereas the water column was homogeneous during the rainy season (April - December). Despite the seasonal changes in the environmental conditions, the expected enhancement in the productivity of the system during the dry season (i.e., higher biomass and abundance of the mesozooplankton) only occurred in February 2012. Contrary to expectations, ichthyoplankton abundance was higher during the rainy season, when the assemblage was dominated by the larvae of anchovy (Cetengraulis mysticetus) and an unidentified Gobiidae. Conclusions: The entrance of upwelled waters into Ensenada de Utría is an important factor modulating the seasonal changes observed in the water column. However, there is high interannual variability in the response of mesozooplankton communities to the upwelling events. Because upwelled waters are oxygen-depleted and more acidic, the entrance of upwelled waters into Ensenada de Utría could be causing physiological stress to the benthic and pelagic organisms inhabiting the deepest zones of the cove. This condition may worsen in the future given the predicted increase of deoxygenation and ocean acidification due to climate change.
\end{abstract}

Key words: mesozooplankton; ichthyoplankton; hypoxia; Eastern Tropical Pacific; Colombia.

Valencia, B., Alan Giraldo, Rivera-Gómez, M., Izquierdo-Peña, V., \& Cuellar-Chacón, A. (2019). Effects of seasonal upwelling on hydrography and mesozooplankton communities in a Pacific tropical cove off Colombia. Revista de Biología Tropical, 67(4), 945-962.

Seasonality driven by upwelling is known to play a major role in changing the hydrography and plankton community structure in coastal and oceanic environments (Fiedler \& Talley, 2006). In the Eastern Tropical Pacific
(ETP), seasonal upwelling occurs in the gulfs of Tehuantepec (Mexico), Papagayo (Costa Rica), and Panama (Panama) modulated by the annual displacement of the Intertropical Convergence Zone (ITCZ) (Amador, Alfaro, 
Lizano, \& Magaña, 2006). During the dry season (January - March), the ITCZ reaches its southernmost position in March $\left(\sim 1{ }^{\circ} \mathrm{N}\right)$ allowing passage of trans-isthmic wind jets that blow offshore (Amador et al., 2006). The jets produce mixing and upwelling (cyclonic gyre) over the shelf and oceanic waters of the gulfs, where colder and saltier subsurface waters are transported into the upper water column. This decreases surface temperature and dissolved oxygen concentrations and increases salinity and nutrients at upwelling sites, resulting in enhanced plankton abundance and biomass (Fernández-Álamo \& Färber-Lorda, 2006; Pennington et al., 2006; Willet, Leben, \& Lavín, 2006). In contrast, over the course of the rainy season (April - December) the ITCZ reaches its northernmost position $\left(\sim 10^{\circ} \mathrm{N}\right)$, typically in September. During this season, the wind jets are no longer observed, precipitation increases, and the waters of the gulfs become warmer, fresher, and less productive (Amador et al., 2006; Fernández-Álamo \& Färber-Lorda, 2006; Pennington et al., 2006).

Despite the effects of seasonal changes in the hydrography on the regional dynamics of plankton communities and fisheries, the responses of plankton communities to seasonality in the three gulfs have only been characterized in a few studies (Legeckis, 1988; Fernández-Álamo, Sanvicente-Añorve, \& Alameda-De-La-Mora, 2000; Müller-Karger \& Fuentes-Yaco, 2000; Rodríguez-Rubio \& Stuardo, 2002; Färber-Lorda, Lavín, \& Guerrero-Ruiz, 2004; D’Croz \& O’Dea, 2007). In coastal environments, seasonality of the hydrography and plankton communities have been mostly described in Bahía Culebra in the Gulf of Papagayo (Bednarski \& MoralesRamírez, 2004; Rixen, Jiménez, \& Cortés, 2012; Rodríguez-Sáenz \& Morales-Ramírez, 2012) and inside the Gulf of Panama (Smayda, 1966; Forsbergh, 1969; D’Croz, Del Rosario, \& Gómez, 1991; D'Croz \& Robertson, 1997; Miglietta, Rossi, \& Collin, 2008). However, upwelled waters in the Gulf of Panama influence the entire Panama Bight, an area that includes coastal and oceanic waters of Ecuador,
Colombia, and Panama. Knowledge about the seasonal changes in hydrography and their effects on plankton communities is particularly scarce in the Northern Pacific coast of Colombia. In this region, a stronger influence of upwelled waters on estuarine environments is expected due to the narrow continental shelf $(\sim 15 \mathrm{~km})$, the influence of the northward Colombia Current (>100 km wide) during the dry season, and the potential effect of cyclical tidal currents (Cantera, 1993).

The Northern Pacific coast of Colombia is recognized for its high biodiversity, and fisheries repopulation and conservation efforts have been implemented in the protected area of Ensenada de Utría (UAESPNN, 2007). To date, only several studies have evaluated the diversity of specific mesozooplankton groups in the region, including the work on hyperiid amphipods (Valencia \& Giraldo, 2009) and copepods in Bahía Cupica (Jerez-Guerrero, Criales-Hernández, \& Giraldo, 2017), further north of Ensenada de Utría. It is important to further describe these communities because mesozooplankton play a key role in pelagic food webs, linking unicellular organisms and higher trophic levels (Fernández-Álamo \& Färber-Lorda, 2006). Additionally, it is crucial to understand the seasonal changes in the physical-chemical conditions of the water column, as these could affect the physiology, ecology, and productivity of planktonic, nektonic, and benthonic organisms inhabiting Ensenada de Utría.

In this study, we evaluate the effects that the seasonal upwelled waters over the Panama Bight have on Ensenada de Utría by addressing the following questions: (1) Do the seasonal upwelled waters over the Panama Bight influence the hydrographic structure of the water column in Ensenada de Utría? (2) Does mesozooplankton abundance and biomass in Ensenada de Utría increase during the dry season as occurs in the shelf and oceanic waters of the Panama Bight? (3) Does ichthyoplankton abundance in Ensenada de Utría increase during the dry season as a response to the productivity enhancement in the system? (4) 
Does mesozooplankton and ichthyoplankton community structure in Ensenada de Utría change between seasons? We hypothesize that the seasonal changes in the hydrography and mesozooplankton communities that occur in the Panama Bight between the dry (influenced strongly by upwelling) and rainy seasons (influenced strongly by coastal runoff) also affect the pelagic coastal ecosystem of Ensenada de Utría. Specifically, we expect that during the dry season, subsurface waters inside the cove become colder, saltier, and oxygen depleted, resulting in an increase in mesozooplankton abundance and biomass.

\section{MATERIALS AND METHODS}

Study site: Ensenada de Utría $\left(06^{\circ} 04^{\prime} \mathrm{N}\right.$ $\& 77^{\circ} 23^{\prime} \mathrm{W}$ ) is a remote and shallow cove belonging to the National Natural Park Utría, Northern Pacific coast of Colombia, that has highly valued ecosystems such as rocky and sandy shores, mangrove forests, and coral reefs (UAESPNN, 2007) (Fig. 1). The weather is characterized by warm atmospheric temperatures (annual mean: $26.2{ }^{\circ} \mathrm{C}$ ), high humidity ( $90 \%$ ), and high precipitation levels with an annual mean of $6508 \mathrm{~mm}$ (range: 94.5 $\mathrm{mm}$ in March - $1162 \mathrm{~mm}$ October) (Eslava, 1993; Rangel \& Arellano, 2004). The cove has an extension of $6 \mathrm{~km}$ and a width of $800 \mathrm{~m}$ (middle zone), and is surrounded by mountains of small elevation with numerous creeks discharging into it (UAESPNN, 1998). Tides are semidiurnal with 5-6 m amplitude, and there is a permanent entrance of coastal waters in the southern side of the cove.

Sampling and processing: Four field campaigns were carried out to characterize the seasonality of the hydrographic structure of the water column and mesozooplankton communities at Ensenada de Utría, two during the dry season (February 2012, February 2013) and two during the rainy season (December 2011, October 2013). Oceanographic sampling took place at nine stations along the cove (depth range: $1.2-66.5 \mathrm{~m}$ ), covering the inner (stations 1-3), middle (stations 4-6), and outer zones (stations 7-9; Fig. 1). At each sampling station, temperature and salinity were recorded with a CTD Seabird-19 until $60 \mathrm{~m}$ (or close to the bottom), except during February 2012, when due to logistical constrains, the vertical profiles were obtained only at one station of each zone (stations 3, 5, and 8) using a YSI85 from water collected every $2 \mathrm{~m}$ with a $5 \mathrm{~L}$ Niskin bottle. Dissolved oxygen concentration was recorded at discrete depths $(1,10$, and 30 m) with a YSI85 from water collected with the Niskin bottle. Transparency of the water column was recorded using a Secchi disk $(20 \mathrm{~cm}$ diameter). In addition to the sampling along the cove, in each field campaign, the hydrographic structure of the water column was characterized at a fixed point in the middle zone of the cove during a tidal cycle (depth range: 24.7 - 31.7 m, Fig. 1), where temperature, salinity, and dissolved oxygen concentration were recorded every hour during 12 hours.

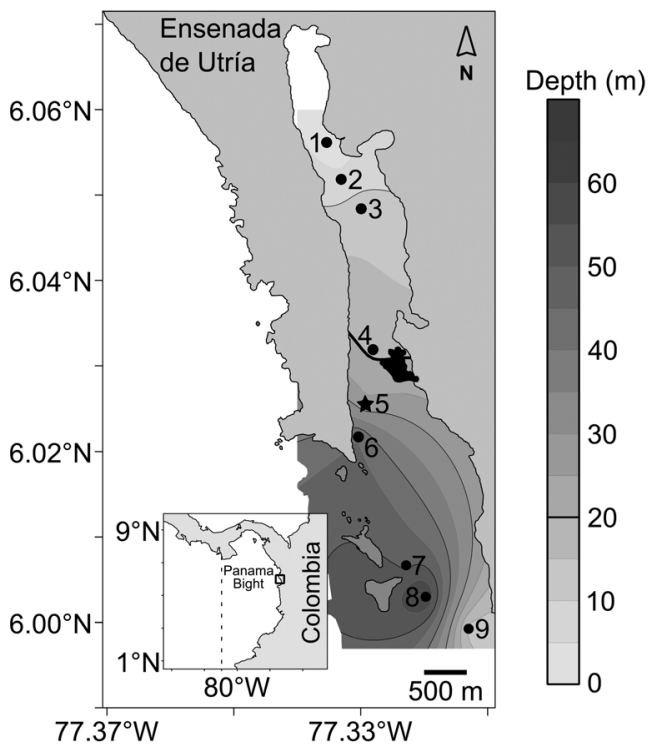

Fig. 1. Map showing the sampling stations along Ensenada de Utría in the Northern Pacific coast of Colombia. The station where environmental data were collected hourly during a $12 \mathrm{~h}$ period is indicated with a black star. The 20 $\mathrm{m}$ isobath is highlighted. The location of the coral reef is indicated in black in the middle zone of the cove. 
To characterize the mesozooplankton communities, samples were collected by horizontal tows using a Bongo net $(0.3 \mathrm{~m}$ diameter, 300 $\mu \mathrm{m}$ mesh size) equipped with a General Oceanics flowmeter to quantify the volume of water filtered. Due to logistical constraints during December 2011, samples were collected with a conical net $(0.3 \mathrm{~m}$ diameter, $300 \mu \mathrm{m}$ mesh size), and in this case, two consecutive tows were performed at each station. Mesozooplankton samples were preserved in $5 \%$ buffered formalin. Once in the laboratory, dry weight biomass $\left(60{ }^{\circ} \mathrm{C}, 24 \mathrm{~h}\right)$ was estimated using an analytical balance (Radwag AS 220/C/2, \pm $0.0001 \mathrm{~g}$ ) from the samples collected in one of the cod ends. Major groups were quantified from the whole sample or subsamples splits of the second cod end (1/2 -1/8) and were identified using the taxonomic keys of Boltovskoy (1999) and Gasca \& Suárez-Morales (1996). In addition, during December 2011 and February 2012, fish larvae were sorted from the whole samples and identified to the lowest taxonomic level possible based on the keys of BeltránLeón and Ríos (2000), and Moser (1996). Mesozooplankton biomass and abundance, as well as fish larvae abundance were standardized per cubic meter using the estimated volume of water filtered, and are presented as $\mathrm{mg}$ $\mathrm{m}^{-3}$, ind $\mathrm{m}^{-3}$, and ind $1000 \mathrm{~m}^{-3}$, respectively.

Data analyses: Variability of the environmental conditions between field campaigns (temperature, salinity, dissolved oxygen concentration, and Secchi depth) was evaluated at $1 \mathrm{~m}(\mathrm{n}=9$ stations $), 10 \mathrm{~m}(\mathrm{n}=7$ stations $)$, and $30 \mathrm{~m}$ ( $\mathrm{n}=3$ stations) using the non-parametric Kruskal-Wallis test. Likewise, KruskalWallis test was used to evaluate differences in mesozooplankton abundance and biomass between field campaigns. A multiple pairwisecomparison test was applied when differences were significant $(\mathrm{P}<0.05)$. In the case of ichthyoplankton abundance, the non-parametric Wilcoxon test was used to evaluate differences between field campaigns (December 2011 and February 2012). Differences in composition and abundance (square-root transformed) of the major mesozooplankton groups between field campaigns were evaluated using non-metric multidimensional scaling (nMDS) based on the Bray-Curtis similarity index. Only the groups that presented a relative abundance $>1 \%$ in any of the field campaigns were considered for the analysis (Appendicularia, Bivalvia, Brachiopoda, Chaetognatha, Copepoda, Decapoda, Gastropoda, and Ostracoda). A Spearman correlation with a Bonferroni correction was used to evaluate which environmental variables could be influencing variability of mesozooplankton communities between field campaigns. Nonparametric analyses were used because the assumptions of normality and homogeneity of variances were not met, even after data were logarithmically transformed by $\log 10(\mathrm{x})$. Data analyses were performed in R (R Core Team, 2017). Unless otherwise noted, results will be presented as mean and standard deviation (SD).

In addition, to characterize the hydrographic structure of the water column, the stratification index $(d \rho / d z)$ was calculated for each field campaign as the density difference ( $\rho 2$ - $\rho 1)$ normalized to the depth difference $(z 2-z 1)$. The index was calculated only for the three stations that were deeper than $30 \mathrm{~m}$ (see Fig. 1) using the mean density from 1-5 m ( $\rho 1)$ and from $31-35 \mathrm{~m}(\rho 2)$. The TEOS-10 Manual was considered to calculate in situ density from absolute salinity and conservative temperature implementing the TEOS-10 Matlab routine (IOC, SCOR, \& IAPSO, 2010).

\section{RESULTS}

Environmental conditions: Surface waters at Ensenada de Utría were warm $\left(>25^{\circ} \mathrm{C}\right)$ and presented low salinities throughout the study period, in particular during the rainy season $(<25)$, as is typical of waters in the ETP (Table 1). A clear seasonal pattern was not evident for temperature and dissolved oxygen concentration at $1 \mathrm{~m}$ and $10 \mathrm{~m}$ (Table $1)$; measurements were significantly different between field campaigns. Temperatures at $1 \mathrm{~m}$ were significantly lower in December 2011 $\left(25.8 \pm 0.2{ }^{\circ} \mathrm{C}\right.$, mean $\left.\pm \mathrm{SD}\right)$ and significantly 
TABLE 1

Environmental conditions at Ensenada de Utría, Northern Colombian Pacific, during the rainy (R: December 2011, October 2013) and dry seasons (D: February 2012, February 2013)

\begin{tabular}{|c|c|c|c|c|c|c|}
\hline & \multicolumn{2}{|c|}{ Temperature $1 \mathrm{~m}\left({ }^{\circ} \mathrm{C}\right)$} & \multicolumn{2}{|c|}{ Temperature $10 \mathrm{~m}\left({ }^{\circ} \mathrm{C}\right)$} & \multicolumn{2}{|c|}{ Temperature $30 \mathrm{~m}\left({ }^{\circ} \mathrm{C}\right)$} \\
\hline & Mean \pm sd & Range & Mean \pm sd & Range & Mean \pm sd & Range \\
\hline Dec.2011 (R) & $25.8 \pm 0.2$ & $25.5-26.0$ & $26.2 \pm 0.1$ & $26.0-26.3$ & $26.0 \pm 0.1$ & $26.0-26.1$ \\
\hline Feb.2012 (D) & $27.7 \pm 0.2$ & $27.5-27.9$ & $25.2 \pm 0.6$ & $24.8-26.4$ & $16.5 \pm 0.3$ & $16.2-16.8$ \\
\hline Feb.2013 (D) & $27.4 \pm 0.2$ & $27.2-27.6$ & $26.6 \pm 0.5$ & $25.9-27.1$ & $16.0 \pm 0.6$ & $15.5-16.7$ \\
\hline \multirow[t]{3}{*}{ Oct.2013 (R) } & $28.0 \pm 0.3$ & $27.5-28.3$ & $27.8 \pm 0.1$ & $27.7-28.0$ & $26.5 \pm 0.4$ & $26.3-26.8$ \\
\hline & \multicolumn{2}{|c|}{ Salinity $1 \mathrm{~m}$} & \multicolumn{2}{|c|}{ Salinity $10 \mathrm{~m}$} & \multicolumn{2}{|c|}{ Salinity $30 \mathrm{~m}$} \\
\hline & Mean \pm sd & Range & Mean \pm sd & Range & Mean \pm sd & Range \\
\hline Dec.2011 (R) & $22.5 \pm 2.0$ & $18.3-24.5$ & $25.2 \pm 0.1$ & $24.9-25.4$ & $30.3 \pm 0.3$ & $29.9-30.5$ \\
\hline Feb.2012 (D) & $29.4 \pm 0.2$ & $29.0-29.6$ & $31.2 \pm 0.5$ & $30.4-31.7$ & $34.7 \pm 0.2$ & $34.5-34.9$ \\
\hline Feb.2013 (D) & $27.7 \pm 0.7$ & $26.1-28.3$ & $29.0 \pm 0.3$ & $28.6-29.6$ & $34.0 \pm 0.2$ & $33.9-34.2$ \\
\hline \multirow[t]{3}{*}{ Oct.2013 (R) } & $23.9 \pm 0.6$ & $22.9-24.5$ & $28.4 \pm 0.3$ & $27.9-28.7$ & $30.6 \pm 0.2$ & $30.4-30.7$ \\
\hline & \multicolumn{2}{|c|}{ Dissolved oxygen $1 \mathrm{~m}\left(\mathrm{ml} \mathrm{l}^{-1}\right)$} & \multicolumn{2}{|c|}{ Dissolved oxygen $10 \mathrm{~m}\left(\mathrm{ml} \mathrm{l}^{-1}\right)$} & \multicolumn{2}{|c|}{ 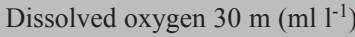 } \\
\hline & Mean \pm sd & Range & Mean \pm sd & Range & Mean \pm sd & Range \\
\hline Dec.2011 (R) & $5.0 \pm 0.2$ & $4.8-5.4$ & $5.0 \pm 0.2$ & $4.7-5.3$ & $4.2 \pm 0.2$ & $4.1-4.4$ \\
\hline Feb.2012 (D) & $4.9 \pm 0.2$ & $4.4-5.2$ & $4.6 \pm 0.2$ & $4.3-5.0$ & $1.0 \pm 0.1$ & $0.9-1.0$ \\
\hline Feb.2013 (D) & $4.1 \pm 0.3$ & $3.6-4.3$ & $4.2 \pm 0.0$ & $4.1-4.3$ & $1.9 \pm 0.7$ & $0.9-2.3$ \\
\hline Oct.2013 (R) & $4.7 \pm 0.1$ & $4.4-4.8$ & $4.6 \pm 0.1$ & $4.5-4.6$ & $4.3 \pm 0.1$ & $4.2-4.3$ \\
\hline
\end{tabular}

sd $=$ standard deviation

higher in October $2013\left(28.0 \pm 0.3^{\circ} \mathrm{C}\right)$. Both of these field campaigns correspond to the rainy season, indicating that there was high interannual variability of the surface temperatures within the cove (Kruskal-Wallis $=27.2, \mathrm{P}<$ $0.0001)$. In contrast, salinities at $1 \mathrm{~m}$ showed the expected seasonal pattern with significantly higher values in February 2012 and February 2013 (dry season) than in December 2011 and October 2013 (rainy season) (Kruskal-Wallis = 28.8, $\mathrm{P}<0.0001)$.

At stations deeper than $20 \mathrm{~m}$, differences between field campaigns in temperature (Kruskal-Wallis $=9.6, \mathrm{P}>0.05$ ), salinity (KruskalWallis $=10.9, \mathrm{P}>0.05)$, and dissolved oxygen concentration (Kruskal-Wallis $=9.4, \mathrm{P}>0.05$ ) were not significant. However, the signal of upwelled waters was evident at the mouth of the cove (depths $>20 \mathrm{~m}$ ) in February 2012 and February 2013 (dry season), when dissolved oxygen concentration and temperature decreased up to $0.9 \mathrm{ml} \mathrm{l}^{-1}$ and almost $10{ }^{\circ} \mathrm{C}$, and salinity increased (Table 1, Fig. 2). In contrast, in December 2011 and October 2013 (rainy season), vertical profiles of temperature and dissolved oxygen concentration until $30 \mathrm{~m}$ were relatively homogeneous (Fig. 2), although the vertical distribution of salinity was more variable due to the higher precipitation levels (December 2011: $361 \pm 676 \mathrm{~mm}^{\text {day }}{ }^{-1}$; February 2012: $47 \pm 121 \mathrm{~mm}^{\text {day }}{ }^{-1}$, measured in situ using a portable pluviometer). As a result of the changes observed in the subsurface waters (dry season: colder and saltier, rainy season: warmer and fresher), the water column was more stratified in February 2012 (stratification index: 0.24) and February 2013 (0.25) during the dry season than in December $2011(0.15)$ and October $2013(0.19)$ during the rainy season.

Despite the differences in precipitation and the structure of the water column between seasons, the depth of the Secchi disk, a measure of the transparency of the water column, did not show a clear seasonal pattern (Kruskal-Wallis $=7.3, \mathrm{P}>0.05)$. Instead, the Secchi depth presented high variability within each field campaign (Fig. 3). 
A

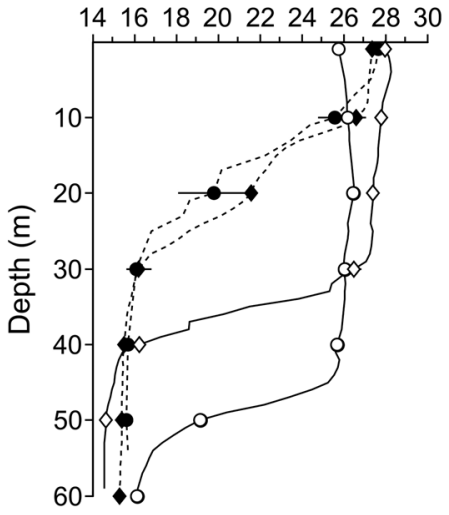

B

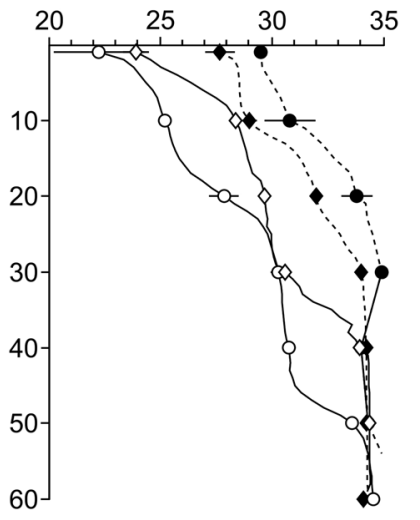

C Dissolved oxygen $\left(\mathrm{ml} \mathrm{I}^{-1}\right)$

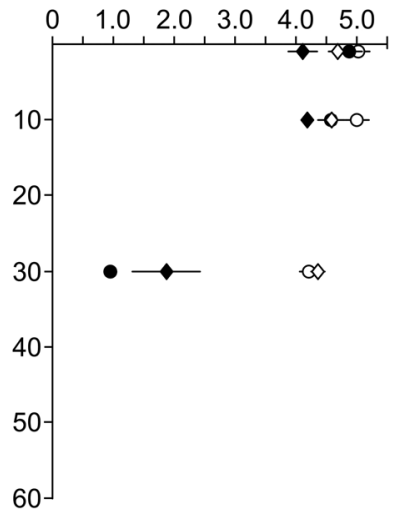

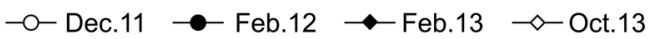

Fig. 2. Vertical profiles of temperature (A.), salinity (B.), and dissolved oxygen concentration (C.) in Ensenada de Utría, Northern Colombian Pacific, during the rainy (December 2011, October 2013) and dry seasons (February 2012, February 2013). Mean \pm standard deviation.

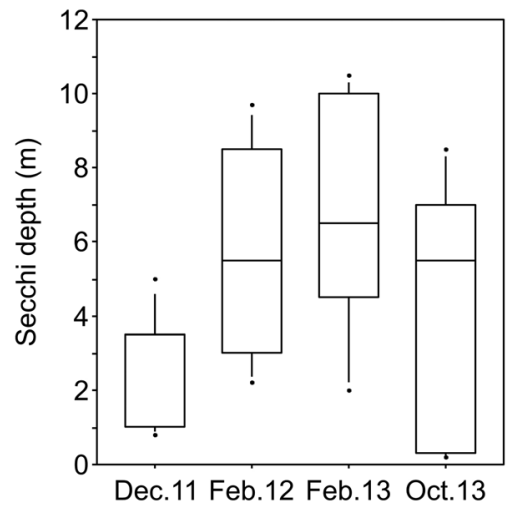

Fig. 3. Secchi depth in Ensenada de Utría, Northern Colombian Pacific, during the rainy (December 2011, October 2013) and dry seasons (February 2012, February 2013). Boxes and whiskers correspond to 25-75th and 5-95th percentiles, respectively. The horizontal line represents the median and the dots are outliers.

The vertical profiles of temperature, salinity, and dissolved oxygen concentration taken hourly during a $12 \mathrm{~h}$ period in the middle zone of the cove indicate that environmental conditions tended to be more homogeneous throughout the tidal cycle during the rainy season (Fig. 4 and Fig. 5). The homogeneity in the profiles suggests that despite the strong amplitude of the tides (c.a. 5-6 m), the waters entering the cove had similar characteristics to the waters within the cove due to the deeper thermocline during this season (Fig. 4). During the dry season, the entrance of waters into the cove during the rising tide had a stronger effect on the structure of the water column (Fig. 4 and Fig. 5). Waters that entered the cove deepened the isolines during a period of about two hours, suggesting that circulation occurs with waters entering in the surface layers and leaving in the subsurface layers. This circulation pattern was confirmed during a preliminary survey when aluminum drifters at 1 and $10 \mathrm{~m}$ were followed in each field campaign during a tidal cycle (data not shown). It is important to note that during the dry season, our results suggest that benthic organisms inhabiting the middle and outer zones of the cove were exposed to waters with temperatures $\leq 20^{\circ} \mathrm{C}$, salinities $\geq 33$, and low dissolved oxygen concentrations $(<2.0 \mathrm{ml}$ $1^{-1}$; Fig. 4 and Fig. 5).

Mesozooplankton communities: Mesozooplankton biomass (Kruskal-Wallis $=20.4$, $\mathrm{P}<0.001$ ) and abundance (Kruskal-Wallis $=$ $19.7, \mathrm{P}<0.001$ ) did not present a clear seasonal pattern, although both were significantly higher in February 2012 (dry season) than during the 

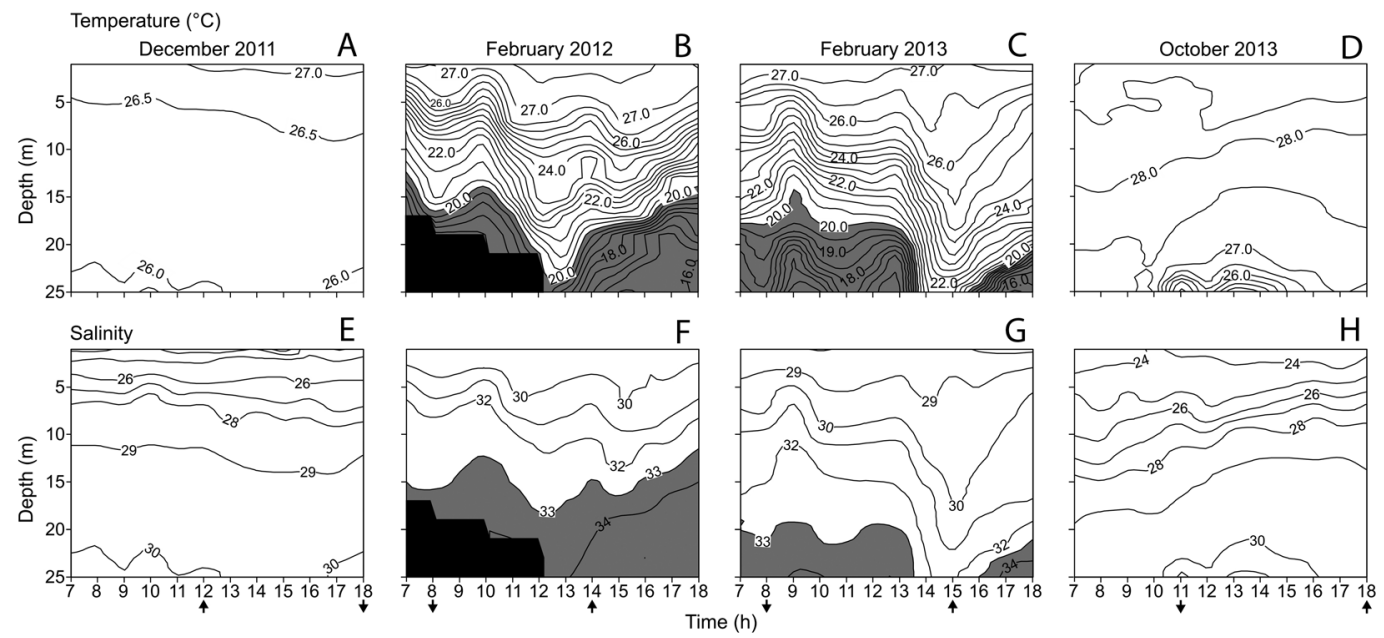

Fig. 4. Temperature and salinity contours in Ensenada de Utría during a $12 \mathrm{~h}$ period during the rainy (December 2011, October 2013) and dry seasons (February 2012, February 2013). Temperature $\left({ }^{\circ} \mathrm{C}\right)$ : A. December 2011, B. February 2012, C. February 2013, and D. October 2013. Salinity: E. December 2011, F. February 2012, G. February 2013, and H. October 2013. Data were collected every hour in the middle zone of the cove from 07:00 to 18:00 (see Fig. 1). Waters with temperatures lower than $20{ }^{\circ} \mathrm{C}$ and salinities higher than 33 are highlighted in gray. Black indicates data unavailable in February 2012. Arrows indicate the time of the maximum (up) or minimum (down) tides according to the tide charts (http:// www.ideam.gov.co).
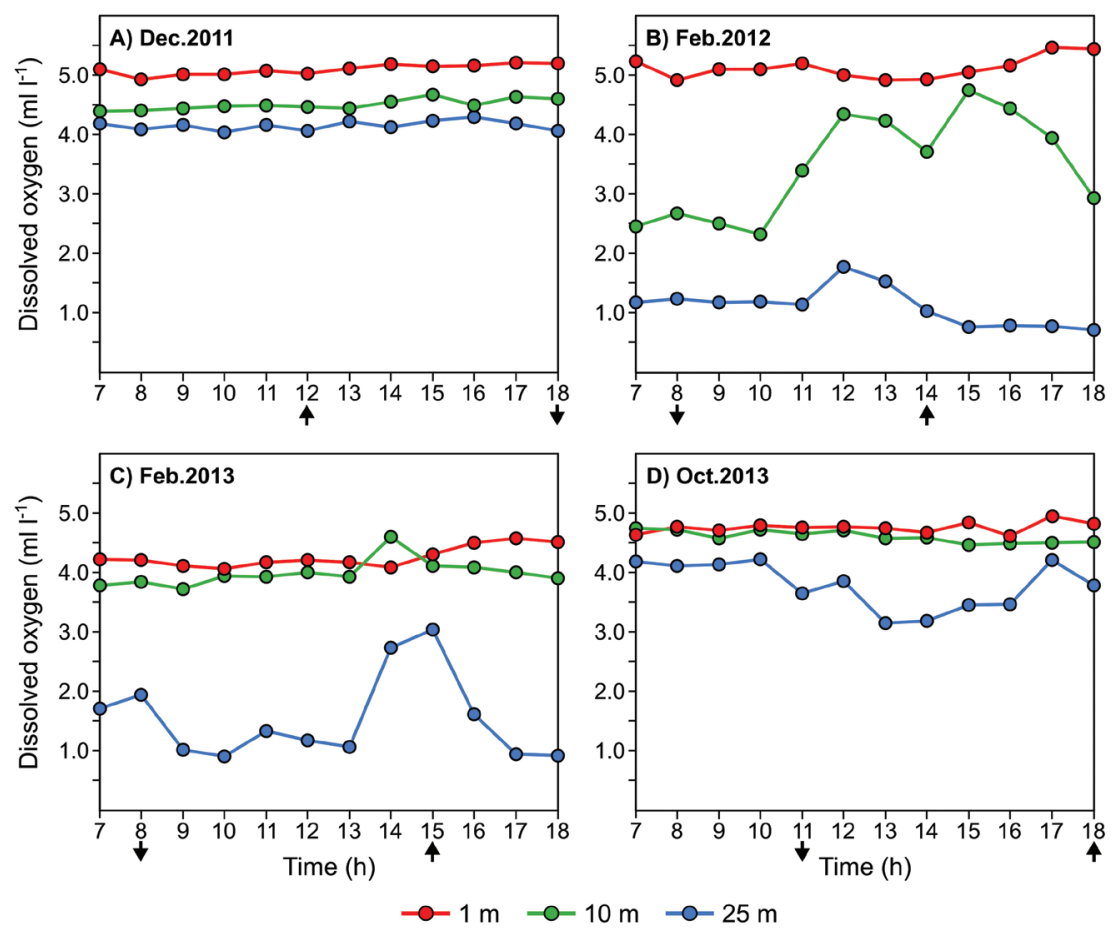

Fig. 5. Dissolved oxygen contours in Ensenada de Utría during a 12 h period during A. December 2011 (rainy season), B. February 2012 (dry season), C. February 2013 (dry season), and D. October 2013 (rainy season). Data were collected every hour in the middle zone of the cove from 07:00 to 18:00 at three discrete depths: $1 \mathrm{~m}, 10 \mathrm{~m}$, and $30 \mathrm{~m}$. Arrows indicate the time of the maximum (up) or minimum (down) tides according to the tide charts (http://www.ideam.gov.co). 
field campaigns of the rainy season (December 2011 and October 2013, Fig. 6). Contrary to expectations, median mesozooplankton biomass and abundance during February 2013 (dry season) were as low as the values registered during December 2011 and October 2013 (rainy season; P $>0.05$, Fig. 6). Mesozooplankton communities were characterized by a high dominance of meroplanktonic larvae, in particular of gastropods during December 2011 at the inner zone, during February 2012 at the inner and middle zones, and during February 2013 at the three zones (Fig. 7). In contrast, crustaceans, mainly copepods and ostracods, dominated the communities during December 2011 at the middle and outer zones, and in October 2013 at the three zones (Fig. 7).

The result of the nMDS suggests that four groups with similar composition and abundance of the major mesozooplankton groups could be identified (Fig. 8). One group was formed by stations of the rainy season (December 2011: five stations, October 2013: five stations), mainly from the middle and outer zones of the cove. A second group contained mainly stations from February 2012 (seven stations). The other two groups were formed by a combination of stations independent of the season. In this case, one group contained stations from the inner zone of the cove (December 2011: two stations, February 2012: two stations), as well as stations from different zones of the cove in February 2013 (five stations). The last group contained stations from the three zones of the cove of February 2013 (four stations) and October 2013 (four stations).

In contrast to mesozooplankton biomass and total abundance, ichthyoplankton abundance was significantly higher in December 2011 (rainy season) than in February 2012 (dry season) (Wilcoxon $=5, \mathrm{P}=0.003$; Fig. 9). The assemblages were dominated by Gobiidae sp.2 (45\%) and Cetengraulis mysticetus (39\%) in December 2011, and by Labrisomus sp. (63 \%) in February 2012 (Table 2, Fig. 9). These species dominated at the three zones along the cove (Fig. 9). Twenty-one morphotypes of ichthyoplankton were identified considering both field campaigns (Table 2). Although fish larvae of the family Gobiidae were abundant, in particular in December 2011 (Table 2, Fig. 9), most individuals collected were in preflexion. Unfortunately, knowledge of the early life stages of this family is still limited in the region, making their identification difficult until a lower taxonomic level.

Mesozooplankton and environmental conditions: Variability of mesozooplankton biomass between field campaigns was inversely associated with temperature at $10 \mathrm{~m}$ (Spearman's $\mathrm{r}=-0.72, \mathrm{P}<0.0001$ ), and positively associated with salinity at $1 \mathrm{~m}$ (Spearman's $\mathrm{r}=0.62, \mathrm{P}<0.0001)$ and $10 \mathrm{~m}$ (Spearman's $r=0.61, P=0.01)$, increasing significantly as temperature decreased and as salinity increased. A similar result was found for mesozooplankton abundance (Table 3). Variability
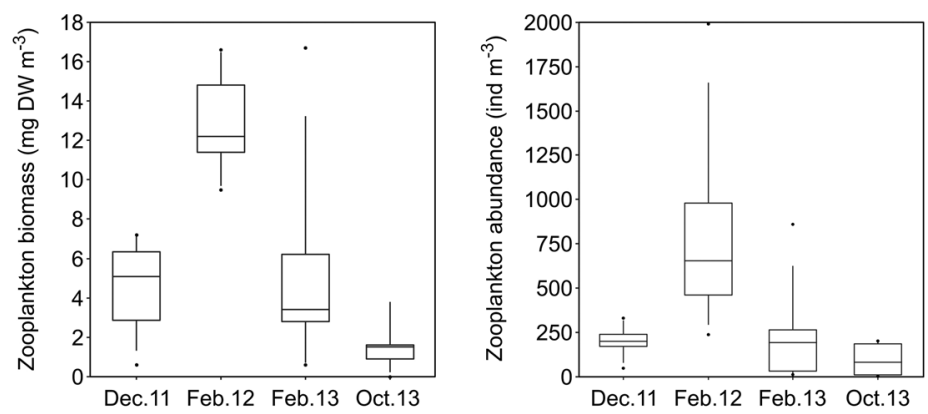

Fig. 6. Mesozooplankton biomass and abundance at Ensenada de Utría, Northern Colombian Pacific, during the rainy (December 2011, October 2013) and dry seasons (February 2012, February 2013). Boxes and whiskers correspond to 25-75th and 5-95th percentiles, respectively. The horizontal line represents the median and the dots represent outliers. 

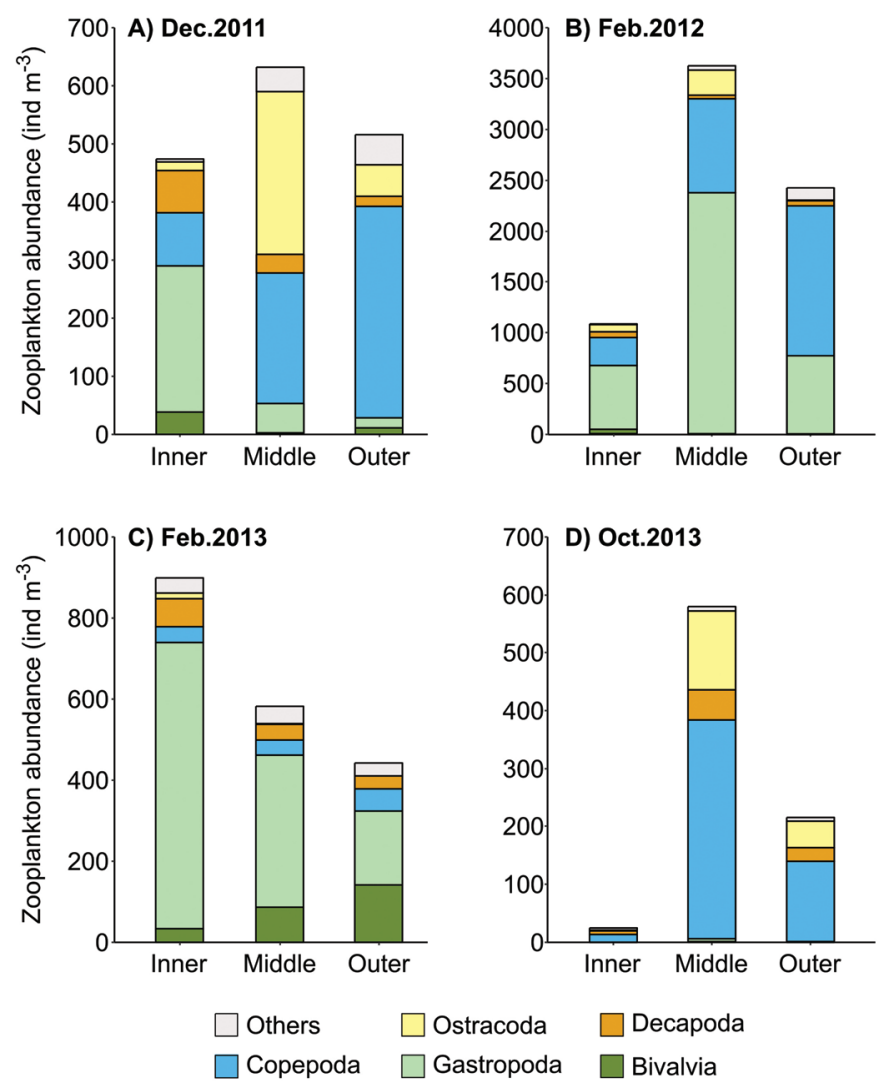

Fig. 7. Mesozooplankton major groups at the inner, middle, and outer zones of Ensenada de Utría, Northern Colombian Pacific during (A.) December 2011 (rainy season), (B.) February 2012 (dry season), (C.) February 2013 (dry season), and (D.) October 2013 (rainy season). Note the different scale on the y-axis.

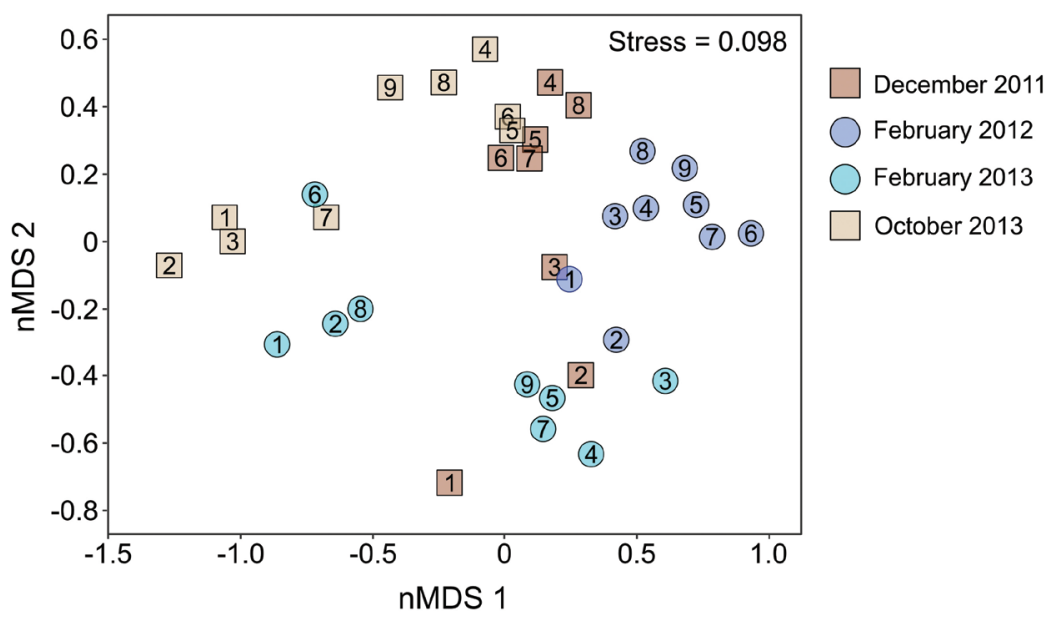

Fig. 8. Mesozooplankton community structure evaluated using non-metric multidimensional scaling (nMDS) in Ensenada de Utría, Northern Pacific coast of Colombia. The symbols indicate if the samples were collected during the rainy season (squares: December 2011 and October 2013) or the dry season (circles: February 2012 and February 2013). Stations are indicated inside the symbols. 


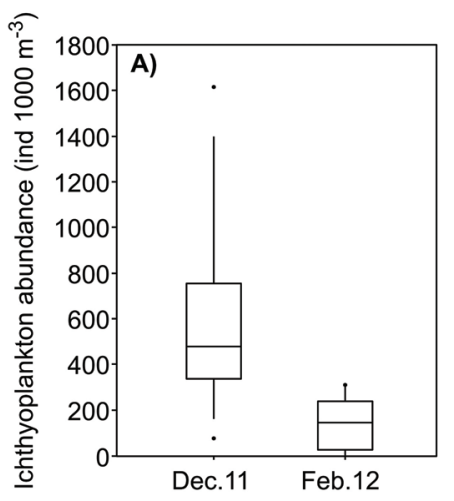

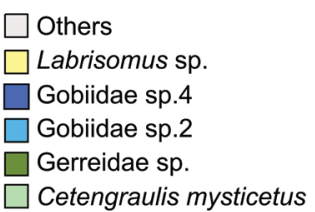
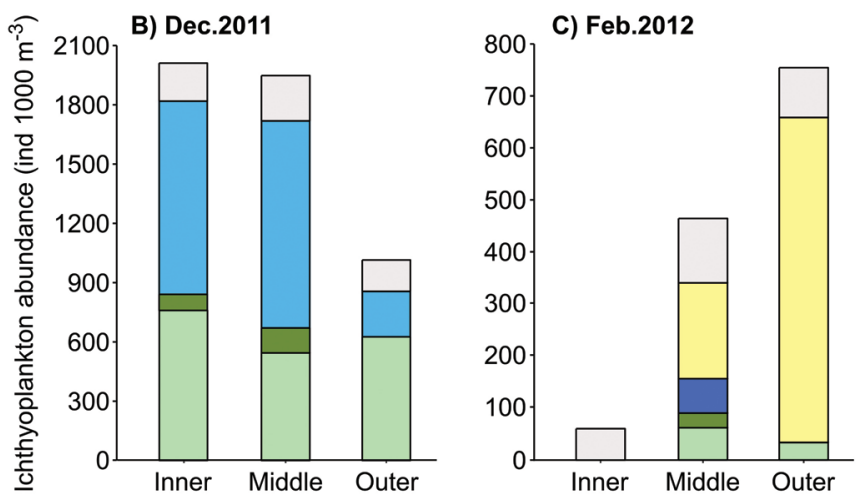

Fig. 9. Variability of ichthyoplankton abundance in Ensenada de Utría, Northern Pacific coast of Colombia. A. Ichthyoplankton total abundance during the rainy (December 2011) and dry seasons (February 2012). Ichthyoplankton species composition at the inner, middle, and outer zones during B. the rainy season (December 2011) and C. the dry season (February 2012). Note the different scale on the y-axis.

of ichthyoplankton abundance between field campaigns was inversely associated with temperature at $1 \mathrm{~m}$ (Spearman's $\mathrm{r}=-0.75, \mathrm{P}=$ 0.01 ; Table 3 ). Variability of mesozooplankton communities was not associated with changes in dissolved oxygen concentration neither at 1 $\mathrm{m}$ or $10 \mathrm{~m}(\mathrm{P}>0.05$; Table 3$)$.

\section{DISCUSSION}

Seasonal changes in the hydrographic structure of the water column and mesozooplankton communities at Ensenada de Utría, a tropical cove in the Northern Pacific coast of Colombia, were influenced by upwelled waters over the Panama Bight during the dry season (January - March), and by coastal processes such as raining and runoff during the rainy season (April - December). Surface waters in the cove varied due to the seasonal changes in the weather, and presented warm temperatures and low salinities throughout the year, as it is typical in the Panama Bight where the highest precipitation levels occur (Fiedler \& Talley, 2006). During the rainy season, the high cloud cover, high precipitation levels, and the discharge of numerous small creeks into the cove were the main factors modulating the temperatures and salinities at the surface, reflected in salinities lower than 25 and significantly warmer waters in October 2013. The low salinities in combination with the warmer temperatures during the rainy season were also reflected in a less stratified water column compared to the dry 
TABLE 2

Relative abundance (\%) of ichthyoplankton in Ensenada de Utría, Northern Pacific coast of Colombia, during the rainy (December 2011) and dry seasons (February 2012)

\begin{tabular}{|c|c|c|c|}
\hline Family & Species & Dec.2011 & Feb.2012 \\
\hline Achiridae & Achirus sp. & 0.3 & - \\
\hline \multirow[t]{2}{*}{ Carangidae } & Chloroscombrus orqueta & 0.3 & - \\
\hline & Seriola lalandi & 1.1 & - \\
\hline Engraulidae & Cetengraulis mysticetus & 38.8 & 7.4 \\
\hline Gerreidae & Gerreidae sp. & 4.2 & 2.2 \\
\hline \multirow[t]{2}{*}{ Gobiesocidae } & Gobiesox sp.1 & - & 2.0 \\
\hline & Gobiesox sp.2 & 0.4 & - \\
\hline \multirow[t]{4}{*}{ Gobiidae } & Gobiidae sp.1 & - & 2.4 \\
\hline & Gobiidae sp.2 & 45.3 & - \\
\hline & Gobiidae sp.4 & - & 5.1 \\
\hline & Gobiidae sp.5 & - & 2.6 \\
\hline Haemulidae & Haemulidae sp. & - & 2.2 \\
\hline Labrisomidae & Labrisomus sp. & - & 63.3 \\
\hline Myctophidae & Myctophidae sp & 1.4 & - \\
\hline Photichthydae & Vinciguerria lucetia & 0.4 & - \\
\hline \multirow[t]{2}{*}{ Sciaenidae } & Menticirrhus sp. & 0.4 & - \\
\hline & Sciaenidae sp. & 1.4 & 2.6 \\
\hline Scombridae & Scomberomorus sp. & 0.3 & - \\
\hline \multirow[t]{2}{*}{ Serranidae } & Diplectrum sp. & 0.3 & - \\
\hline & Serranus sp. & 0.4 & - \\
\hline Synodontidae & Synodus sp. & - & 2.6 \\
\hline Unidentified & - & 4.9 & 7.5 \\
\hline Total & & 100 & 100 \\
\hline
\end{tabular}

TABLE 3

Spearman correlation analysis between environmental conditions and mesozooplankton in Ensenada de Utría, Northern Colombian Pacific, during December 2011, February 2012, February 2013, and October 2013

\begin{tabular}{|c|c|c|c|c|c|c|}
\hline & \multicolumn{4}{|c|}{ Mesozooplankton } & \multirow{2}{*}{\multicolumn{2}{|c|}{$\begin{array}{c}\text { Ichthyoplankton } \\
\text { Abundance }\end{array}$}} \\
\hline & \multicolumn{2}{|c|}{ Biomass } & \multicolumn{2}{|c|}{ Abundance } & & \\
\hline & $\mathrm{r}$ & $\mathrm{p}$-value & $\mathrm{r}$ & p-value & $\mathrm{r}$ & $\mathrm{p}$-value \\
\hline \multicolumn{7}{|c|}{ Temperature $\left({ }^{\circ} \mathrm{C}\right)$} \\
\hline $1 \mathrm{~m}$ & -0.02 & 1.00 & 0.05 & 1.00 & -0.75 & 0.01 \\
\hline $10 \mathrm{~m}$ & -0.72 & $<0.0001$ & -0.63 & 0.01 & 0.53 & 0.77 \\
\hline \multicolumn{7}{|l|}{ Salinity } \\
\hline $1 \mathrm{~m}$ & 0.62 & $<0.0001$ & 0.54 & 0.01 & -0.61 & 0.11 \\
\hline $10 \mathrm{~m}$ & 0.61 & 0.01 & 0.55 & 0.04 & -0.65 & 0.20 \\
\hline \multicolumn{7}{|c|}{ Dissolved oxygen (ml/l) } \\
\hline $1 \mathrm{~m}$ & 0.33 & 0.94 & 0.39 & 0.35 & 0.18 & 1.00 \\
\hline $10 \mathrm{~m}$ & -0.04 & 1.00 & 0.16 & 1.00 & 0.56 & 0.85 \\
\hline
\end{tabular}

season, similar to what has been documented in the Northern Pacific coast of Colombia (JerezGuerrero et al., 2017) and in the Gulf of Panama (Smayda, 1966; Forsbergh, 1969; D'Croz, Kwiecinski, Maté, Gómez, \& Del Rosario,
2003). During the dry season, the decrease in cloud cover, precipitation, and runoff corresponded with an increase in surface salinities within the cove. Seasonal differences in runoff were not reflected in differences in Secchi 
disk readings. This result is consistent with a finding by D'Croz and Robertson (1997), who attributed the lack of seasonality in transparency in the Gulf of Panama to both an increase in suspended sediments due to higher riverine runoff during the rainy season and an increase in plankton abundance due to upwelling during the dry season.

Subsurface waters at Ensenada de Utría were influenced by the seasonal changes that occur over the oceanic and shelf waters of the Panama Bight, where wind mixing and upwelling modify the water column during the dry season (Rodríguez-Rubio \& Stuardo, 2002; Rodríguez-Rubio, Schneider, \& Abarca del Río, 2003; Devis-Morales, Schneider, Montoya-Sánchez, \& Rodríguez-Rubio, 2008). These waters are transported northward along the Pacific coast of Colombia by the Colombia Current (Devis-Morales et al., 2008), and likely influence coastal environments due to the narrow continental shelf and the strong tidal cycles. In Ensenada de Utría, the signal of upwelled waters during the dry season was evident in the subsurface waters in the middle and outer zones of the cove, where temperature and dissolved oxygen concentrations decreased, and salinity increased. Therefore, subsurface waters in the cove followed the expected seasonal pattern that has been documented in Bahía Culebra in the Gulf of Papagayo, Costa Rica (Alfaro et al., 2012), in coastal waters of the Gulf of Panama (Smayda, 1966; Forsbergh, 1969; D'Croz et al., 1991; D'Croz \& Robertson, 1997; D’Croz et al., 2003), and in Bahía Cupica (Jerez-Guerrero et al., 2017) and Isla Gorgona in Colombia (Giraldo, RodríguezRubio, \& Zapata, 2008; Valencia \& Giraldo, 2012). However, whereas in Bahía Culebra (Rixen et al., 2012) and in Bahía de Panamá (Smayda, 1966; D’Croz \& Robertson, 1997) the signal of upwelled waters can be detected at the surface, in Ensenada de Utría surface waters remained warm throughout the study period.

Considering that upwelled waters are colder, saltier, and oxygen-depleted, the duration and intensity of the upwelling events during the dry season could have a direct impact on the physiology of the organisms inhabiting the deepest areas of the cove, especially on sessile benthic species. To date, possible impacts of the seasonal changes in the water column on the biota at Ensenada de Utría have only been documented for corals. López-Victoria \& Zapata (2018) suggested that the $20 \%$ decline in the live coral coverage observed among 2002-2013 may be a response to the decrease in temperatures during the upwelling season, when temperatures dropped up to $22{ }^{\circ} \mathrm{C}$ over the reef. In Las Perlas Archipelago (Panama), Glynn and Stewart (1973) also suggested that thermal stress during upwelling events could be the cause of the decrease in the growth rate of corals.

Sampling at the fixed station at Ensenada de Utría also showed that hypoxic waters are a common feature during the dry season, as has been documented during upwelling events in coastal waters of the Gulf of Panama (Smayda, 1966; D’Croz et al., 1991; D’Croz \& Robertson, 1997). Hypoxia affects benthic and pelagic food webs by altering community (diversity, size, biomass), physiological (growth, reproduction), and behavioral processes (prey capture, predator avoidance; Zhang et al., 2010). While organisms vary in their tolerance to hypoxia depending on the taxonomic group, life stage, and mobility, hypoxia is generally evident by increased habitat avoidance and/or mortality, affecting the services provided by coastal ecosystems (Vaquer-Sunyer \& Duarte, 2008; Zhang et al., 2010). Because the ETP has the largest oxygen minimum zone in the world (Fiedler \& Talley, 2006), and this zone has expanded and shoaled due to climate change (Stramma, Schmidtko, Levin, \& Johnson, 2010), subsurface waters entering at Ensenada de Utría during upwelling events might be bringing waters even colder, saltier, and more oxygen depleted than in previous decades. Unfortunately, due to the lack of a monitoring program of the water column at Ensenada de Utría, it is not possible to evaluate the seasonal and long-term consequences of hypoxia within the cove. 
Despite the physiological stress that upwelled waters could cause, the increase in dissolved nutrients due to upwelling is recognized as the most important process modulating the productivity of the regions of the gulfs of Tehuantepec, Papagayo, and Panama (Fernández-Álamo \& Färber-Lorda, 2006; Pennington et al., 2006). However, information on the seasonal variability on nutrients concentration and the response of the plankton communities is available mainly in shelf and oceanic waters of the gulfs (Pennington et al., 2006; D'Cros \& O'Dea, 2007). Except for the Gulf of Panama (Smayda, 1966; Forsbergh, 1969; D'Croz et al., 1991; D’Croz \& Robertson, 1997; D’Croz et al., 2003), information in other coastal areas is limited. Although nutrients concentration was not quantified in this study, the increase in mesozooplankton biomass and abundance in February 2012 compared to the lower values registered during the rainy season (December 2011, October 2013) indicate that productivity was enhanced at Ensenada de Utría as a response to wind mixing and upwelling during the dry season.

Mesozooplankton biomass and abundance correlate negatively with subsurface temperature and positively with salinity, as a plankton community would be expected to respond to upwelling. Our results are also consistent with the biomass increase in phytoplankton ( 9-fold) and zooplankton ( $\sim 2$-fold) documented by Smayda (1966) in Bahía de Panamá during the dry season. Likewise, our results agree with the seasonal increase in total mesozooplankton biomass and abundance, as well as the increase of specific groups such as copepods, medusae, and hyperiids that has been documented in coastal waters of Bahía Culebra (Bednarski \& Morales-Ramírez, 2004; Rodríguez-Sáenz \& Morales-Ramírez, 2012), Bahía de Panamá (Miglietta et al., 2008), Bahía Cupica (Jerez-Guerrero et al., 2017), and Isla Gorgona (Valencia \& Giraldo, 2012; Giraldo, Valencia, Acevedo, \& Rivera, 2014). In February 2013, although upwelling was evident at Ensenada de Utría in the changes in the environmental conditions of the subsurface waters, these changes were not reflected in an increase of the biomass and abundance of the mesozooplankton. It is possible that changes in the composition of the major groups of the mesozooplankton caused the observed differences. In February 2012, gastropod larvae and copepods were the dominant zooplanktonic groups, whereas in February 2013, although gastropod larvae continued to dominate the community, copepod abundance was considerably reduced.

The high relative abundance of larvae of gastropods, bivalves, and decapods, particularly during the dry season, is consistent with the high diversity of ecosystems present at Ensenada de Utría such as mangroves, sandy and rocky shores, and coral reefs that could function as larvae supply. Although we do not know which ecosystem the gastropod larvae that peaked during the dry season came from, Collin and Ochoa (2016) documented that at least one species of rocky shore intertidal gastropod in Bahía de Panamá showed higher reproductive output during the dry season. The higher abundance of larvae was likely the result of the increase in food availability to the reproductive adults (Collin \& Ochoa, 2016). In contrast, the increase in relative abundance of ostracods during the rainy season, a primarily detritivorous zooplanktonic group (Angel, 1993), suggests that the efficiency of energy transfer in the water column was lower during this period. In Bahía de Panamá, Smayda (1966) documented a shift from a diatom-dominated phytoplankton community during the dry season (larger cells, fewer trophic levels) to a flagellate-dominated community during the rainy season (smaller cells, more trophic levels), suggesting a less efficient water column during the rainy season. Ostracods have also been documented to increase in abundance during the rainy season in Isla Gorgona (Giraldo et al., 2014) and in Bahía Culebra (Bednarski \& Morales-Ramírez, 2004), where they also represent a major component of the mesozooplankton community.

At Ensenada de Utría, it is possible that the increase in food supply during the dry season (i.e., mesozooplankton biomass) was accompanied by a shift in the size structure of the 
mesozooplankton towards a higher proportion of larger organisms, as has been documented for the copepod assemblages in Bahía Cupica, located further north in the Pacific coast of Colombia (Jerez-Guerrero et al., 2017). The concentration and size of the plankton, as well as the timing and overlap with the food, are all important factors modulating the development and survival of fish larvae (Cushing, 1990; Beaugrand, Brander, Lindley, Souissi, \& Reid, 2003; Kristiansen, Drinkwater, Lough, \& Sundby, 2011). Because at Ensenada de Utría mesozooplankton biomass increased in February 2012 (dry season), and the community was potentially composed of larger plankton, it was expected that ichthyoplankton abundance also increased during the dry season. However, fish larvae abundance was higher in December 2011 (rainy season) and thus, it seems likely that other factors besides food concentration are the main drivers of ichthyoplankton abundance. The larvae of anchovies (Cetengraulis mysticetus), a commercially important species, were more abundant in December 2011, which is consistent with their spawning period documented in the Colombian Pacific (October - December) (Beltrán-León, 2002). Likewise, higher abundances of $C$. mysticetus larvae have been found during the rainy season in Bahía Cupica (A. Giraldo, pers. observ.). Besides $C$. mysticetus, the larvae of an unidentified Gobiidae dominated the ichthyoplankton assemblage in December 2011; both are important components of the ichthyoplankton in terms of abundance and frequency of occurrence in the southern Pacific coast of Colombia (Escarria, Beltrán-León, Giraldo, \& Zapata, 2007; CalleBonilla, Giraldo, \& Cuéllar-Chacón, 2017).

During the dry season, Labrisomus sp. dominated the ichthyoplankton assemblage. This genus has also been found to represent an abundant component of the ichthyoplankton in Bahía Cupica (A. Giraldo, pers. observ.). In terms of ichthyoplankton diversity, the number of families found at Ensenada de Utría (14 families) was similar to that documented in Isla Gorgona in the southern Pacific coast of Colombia (14 families by Escarria et al., 2007;
16 families by Calle-Bonilla et al., 2017), but lower than in Bahía Málaga in the central part of the coast (23 families by Medina-Contreras, Cantera, Escarria, \& Mejía-Ladino, 2014). Likely, the spatial-temporal coverage of our study ( 9 stations, 2 months) offers only a snapshot of the true composition of fish larvae that use Ensenada de Utría as a nursery ground. It is also possible that the low number of ichthyoplankton morphotypes registered during this study is due to the variability of the environmental conditions within the cove.

The effects of seasonal upwelling on the structure of the water column and plankton communities have been widely documented in subtropical waters of the eastern Pacific due to the productive fisheries in those regions (e.g., Rykaczewski \& Checkley, 2008; Ayón, Swartzman, Espinoza, \& Bertrand, 2011). We find that in a small and shallow tropical estuary in the Northern Pacific coast of Colombia, Ensenada de Utría, wind mixing and seasonal upwelling over the Panama Bight is also the major drivers modulating the intra-annual variability. The entrance of colder, saltier, and oxygen depleted waters during the dry season modify the structure of the water column in the deepest zones of the cove. Although an increase in mesozooplankton abundance and biomass was expected during the dry season, changes in the composition of the communities were likely associated with the low values registered in February 2013. The high abundance of mollusk (gastropods and bivalves) and crustacean larvae (decapods) highlight the importance of the cove as a nursery ground for the fauna inhabiting diverse and productive ecosystems such as mangroves and coral reefs. Because fish larvae abundance was higher in December 2011 (raining season), despite the increase in productivity in February 2012, other factors besides food concentration are modulating ichthyoplankton abundance in the cove. Continued monitoring of the short and long-term effects of upwelling events on the physiology and productivity of sensitive organisms, including the plankton as well as keystone species such as corals and mangroves, is crucial as these ecosystems 
contribute greatly to the biodiversity and productivity of coastal environments of the ETP and have been shown to be particularly vulnerable to changes in climate.

Ethical statement: authors declare that they all agree with this publication and made significant contributions; that there is no conflict of interest of any kind; and that we followed all pertinent ethical and legal procedures and requirements. All financial sources are fully and clearly stated in the acknowledgements section. A signed document has been filed in the journal archives.

\section{ACKNOWLEDGMENTS}

We specially thank Juan David Acevedo, Gustavo Ramírez, Diego Córdoba, Magdalena Arias, Luis Felipe Piñeros, Juan Guillermo García, and Luis David Lizcano for their direct contributions to sample collections and processing. We thank Maitreyi Nagarkar for correcting the English. We thank the staff of Parque Nacional Natural Utría, specially Julián Olaya and Bismar López, for their support during the field campaigns. We thank three anonymous reviewers who provided helpful feedback. This work was supported by Patrimonio Natural Fondo para la Biodiversidad y Áreas Protegidas, Universidad del Valle, and Conservación Internacional Colombia. This study was performed under the Permit Number PIDB DTPA No. 021-11.

\section{RESUMEN}

Efectos de la surgencia estacional sobre la hidrografía y las comunidades del mesozooplancton en una ensenada tropical del Pacífico colombiano. Introducción: Los efectos de surgencias estacionales sobre la estructura de la columna de agua y las comunidades del mesozooplancton son pobremente entendidos en zonas costeras del Pacífico Oriental Tropical (POT), a pesar de la importancia que tienen los eventos de surgencia en modular la productividad en estas zonas. Objetivo: Evaluar los efectos de la surgencia estacional que ocurre en la Ensenada de Panamá sobre la columna de agua y las comunidades del mesozooplancton en una ensenada tropical del POT. Métodos: Los datos hidrográficos y las muestras de mesozooplankton fueron recolectados durante cuatro campañas de muestreo en la Ensenada de Utría (diciembre 2011, febrero 2012, febrero 2013, octubre 2013), un estuario ubicado en la costa norte del Pacífico colombiano. Las diferencias estacionales en las variables ambientales y bióticas se evaluaron mediante análisis no paramétricos y multivariados. Resultados: Las aguas superficiales fueron cálidas $\left(>25^{\circ} \mathrm{C}\right)$ y presentaron bajas salinidades $(<30)$ a lo largo de todo el periodo de estudio. En contraste, las aguas subsuperficiales fueron más frías $\left(<20{ }^{\circ} \mathrm{C}\right)$, más salinas $(>33)$ y presentaron menores concentraciones de oxígeno disuelto $\left(<2.0 \mathrm{ml} \mathrm{l}^{-1}\right)$ durante la época seca (enero - marzo), mientras que la columna de agua fue homogénea durante la época de lluvias (abril - diciembre). A pesar de los cambios estacionales en las condiciones ambientales, el incremento esperado en la productividad del sistema durante la época seca (i.e., mayor biomasa y abundancia del mesozooplancton) sólo se observó durante febrero 2012. Contrario a lo esperado, la abundancia del ictioplancton fue mayor durante la época de lluvias, periodo en el que el ensamblaje estuvo dominado por un Gobiidae sin identificar y la carduma (Cetengraulis mysticetus). Conclusión: La entrada de aguas de surgencia a la Ensenada de Utría es un factor importante que modula los cambios estacionales observados en la columna de agua. Sin embargo, la respuesta de las comunidades del mesozooplancton ante los eventos de surgencia presentó alta variabilidad interanual. Considerando que las aguas de surgencia son reducidas en oxígeno y más acídicas, la entrada de aguas de surgencia a la Ensenada de Utría podría estar causando estrés fisiológico a los organismos bentónicos y pelágicos que habitan las zonas más profundas de la ensenada. Esta condición podría volverse más severa en el futuro considerando las predicciones que sugieren un incremento de la desoxigenación y acidificación del océano debido al cambio climático.

Palabras clave: mesozooplancton; ictioplancton; hipoxia; Pacífico Oriental Tropical; Colombia.

\section{REFERENCES}

Alfaro, E. J., Cortés, J., Alvarado, J. J., Jiménez, C. E., León, A., Sánchez-Noguera, C., ... Ruiz, E. (2012). Clima y temperatura sub-superficial del mar en Bahía Culebra, Golfo de Papagayo, Costa Rica. Revista de Biología Tropical, 60(Suppl. 2), 159-171.

Amador, J. A., Alfaro, E. J., Lizano, O. G., \& Magaña, V. O. (2006). Atmospheric forcing of the eastern tropical Pacific: A review. Progress in Oceanography, 69, 101-142.

Angel, M. V. (1993). Marine planktonic ostracods: Keys and notes for identification of the species. Shrewsbury, England: Linnean Society of London and the Estuarine and Coastal Sciences Association. 
Ayón, P., Swartzman, G., Espinoza, P., \& Bertrand, A. (2011). Long-term changes in zooplankton size distribution in the Peruvian Humboldt Current System: conditions favouring sardine or anchovy. Marine Ecology Progress Series, 422, 211-222.

Beaugrand, G., Brander, K. M., Lindley, J. A., Souissi, S., \& Reid, P. C. (2003). Plankton effect on cod recruitment in the North Sea. Nature, 426, 661-664.

Bednarski, M., \& Morales-Ramírez, A. (2004). Composition, abundance and distribution of macrozooplankton in Culebra Bay, Gulf of Papagayo, Pacific coast of Costa Rica and its value as bioindicator of pollution. Revista de Biología Tropical, 52, 105-119.

Beltrán-León, B. S. (2002). Changes in the distribution, abundance and spawning season of the anchovy Cetengraulis mysticetus in the Pacific Ocean off Colombia during the Events of El Niño and La Niña. Investigaciones Marinas, 30, 106-107.

Beltrán-León, B. \& Ríos, R. (2000). Estadios tempranos de peces del Pacífico colombiano (Tomo 1). Santa Fe de Bogotá, Colombia: Panamericana Formas e Impresos.

Boltovskoy, D. (1999). South Atlantic zooplankton. Leiden, The Netherlands: Backhuys Publishers.

Calle-Bonilla, I. C., Giraldo, A., \& Cuéllar-Chacón, A. (2017). Spatio temporal variation in the coral fish larvae assembly of Gorgona Island, Colombian Pacific. Boletín de Investigaciones Marinas y Costeras, $46,55-72$.

Cantera, J. R. (1993). Oceanografía. In P. Leyva (Ed.), Colombia Pacífico (Tomo I) (pp. 11-23). Santa Fe de Bogotá, Colombia: Fondo para la Protección del Medio Ambiente FEN.

Collin, R., \& Ochoa, I. (2016). Influence of seasonal environmental variation on the reproduction of four tropical marine gastropods. Marine Ecology Progress Series, 555, 125-139.

Cushing, D. H. (1990). Plankton production and year-class strength in fish populations - an update of the match mismatch hypothesis. Advances in Marine Biology, 26, 249-293.

D’Croz, L., Del Rosario, J. B., \& Gómez, J. A. (1991). Upwelling and phytoplankton in the Bay of Panama. Revista de Biología Tropical, 39, 233-241.

D’Croz, L., Kwiecinski, B., Maté, J. L., Gómez, J. A., \& Del Rosario, J. B. (2003). El afloramiento costero y el Fenómeno de El Niño: Implicaciones sobre los recursos biológicos del Pacífico de Panamá. Tecnociencia, 5, 35-49.

D’Croz, L., \& O’Dea, A. (2007). Variability in upwelling along the Pacific shelf of Panama and implications for the distribution of nutrients and chlorophyll. Estuarine, Coastal and Shelf Science, 73, 325-340.

D’Croz, L., \& Robertson, D. R. (1997). Coastal oceanographic conditions affecting coral reefs on both sides of the isthmus of Panama. Proceedings of the 8th International Coral Reef Symposium, 2, 2053-2058.

Devis-Morales, A., Schneider, W., Montoya-Sánchez, R. A., \& Rodríguez-Rubio, E. (2008). Monsoon-like winds reverse oceanic circulation in the Panama Bight. Geophysical Research Letters, 35, L20607. DOI: 10.1029/2008GL035172

Escarria, E., Beltrán-León, B. S., Giraldo, A., \& Zapata, F. (2007). Ichthyoplankton in the Nacional Natural Park Isla Gorgona (Pacific Ocean of Colombia) during September 2005. Investigaciones Marinas, $35,127-133$.

Eslava, J. A. (1993). Climatología. En P. Leyva (Ed.), Colombia Pacifico (Tomo I) (pp. 136-147). Santa Fe de Bogotá, Colombia: Fondo para la Protección del Medio Ambiente FEN.

Färber-Lorda, J., Lavín, M. F., \& Guerrero-Ruiz, M. A. (2004). Effects of wind forcing on the trophic conditions, zooplankton biomass and krill biochemical composition in the Gulf of Tehuantepec. Deep Sea Research Part II: Topical Studies in Oceanography, 51, 601-614.

Fernández-Álamo, M. A., \& Färber-Lorda, J. (2006). Zooplankton and the oceanography of the eastern tropical Pacific: a review. Progress in Oceanography, 69, 318-359.

Fernández-Álamo, M. A., Sanvicente-Añorve, L., \& Alameda-De-La-Mora, G. (2000). Copepod assemblages in the Gulf of Tehuantepec, Mexico. Crustaceana, $73,1139-1153$

Fiedler, P. C., \& Talley, L. D. (2006). Hydrography of the eastern tropical Pacific: A review. Progress in Oceanography, 69, 143-180.

Forsbergh, E. D. (1969). On the climatology, oceanography and fisheries of the Panama Bight. Inter-American Tropical Tuna Commission Bulletin, 14, 46-385.

Gasca, R., \& Suárez-Morales, E. (1996). Introducción al estudio del zooplancton marino. México, D.F., México: El Colegio de la Frontera Sur (ECOSUR), Consejo Nacional de Ciencia y Tecnología.

Giraldo, A., Rodríguez-Rubio, E., \& Zapata, F. (2008). Condiciones oceanográficas en isla Gorgona, Pacífico oriental tropical de Colombia. Latin American Journal of Aquatic Research, 36, 121-128.

Giraldo, A., Valencia, B., Acevedo, J. D., \& Rivera, M. (2014). Fitoplancton y zooplancton en el área marina 
protegida de Isla Gorgona, Colombia, y su relación con variables oceanográficas en estaciones lluviosa y seca. Revista de Biología Tropical, 62(Suppl. 1), 117-134.

Glynn, P. W., \& Stewart, R. H. (1973). Distribution of coral reefs in the Pearl islands (Gulf of Panama) in relation to thermal conditions. Limnology and Oceanography, $18,367-379$.

IOC, SCOR, \& IAPSO. (2010). The international thermodynamic equation of seawater - 2010: Calculation and use of thermodynamic properties. Intergovernmental Oceanographic Commission, Manuals and Guides No. 56. París, Francia: UNESCO.

Jerez-Guerrero, M., Criales-Hernández, M. I., \& Giraldo, A. (2017). Copépodos epipelágicos en Bahía Cupica, Pacífico colombiano: composición de especies, distribución y variación temporal. Revista de Biología Tropical, 65, 1046-1061.

Kristiansen, T., Drinkwater, K. F., Lough, R. G., \& Sundby, S. (2011). Recruitment variability in North Atlantic cod and match-mismatch dynamics. PLoS One, 6, e17456. DOI: 10.1371/journal.pone.0017456

Legeckis, R. (1988). Upwelling off the Gulfs of Panama and Papagayo in the tropical Pacific during March 1985. Journal of Geophysical Research: Oceans, 93, 15485-15489.

López-Victoria, M., \& Zapata, F. A. (2018). Coral cover decline on La Chola reef (Eastern Tropical Pacific). Boletín de Investigaciones Marinas y Costeras, 47, 107-116.

Medina-Contreras, D., Cantera, J., Escarria, E., \& MejíaLadino, L. M. (2014). Distribution and density of ichthyoplankton in the Bahía Málaga estuary, Pacific coast of Colombia (September 2009-February 2010). Boletín de Investigaciones Marinas y Costeras, 43, 107-119.

Miglietta, M. P., Rossi, M., \& Collin, R. (2008). Hydromedusa blooms and upwelling events in the Bay of Panama, Tropical East Pacific. Journal of Plankton Research, 30, 783-793.

Moser, H. G. (1996). The early stages of fishes in the California Current Region. CalCOFI Atlas, 33. La Jolla, United States: Allen Press.

Müller-Karger, F. E., \& Fuentes-Yaco, C. (2000). Characteristics of wind-generated rings in the eastern tropical Pacific Ocean. Journal of Geophysical Research: Oceans, 105, 1271-1284.

Pennington, J. T., Mahoney, K. L., Kuwahara, V. S., Kolber, D. D., Calienes, R., \& Chavez, F. P. (2006).
Primary production in the eastern tropical Pacific: A review. Progress in Oceanography, 69, 285-317.

R Core Team (2017). R: A language and environment for statistical computing. R Foundation for Statistical Computing. Vienna, Austria. Retrieved from https:// www.R-project.org

Rangel, J. O., \& Arellano, H. (2004). Clima del Chocó biogeográfico de Colombia. En J. O. Rangel (Ed.), Colombia diversidad biótica IV. El Chocó biogeográfico, Costa Pacífica (pp. 39-82). Santa Fe de Bogotá, Colombia: Universidad Nacional de Colombia.

Rixen, T., Jiménez, C., \& Cortés, J. (2012). Impact of upwelling events on the sea water carbonate chemistry and dissolved oxygen concentration in the Gulf of Papagayo (Culebra Bay), Costa Rica: Implications for coral reefs. Revista de Biología Tropical, 60, 187-195.

Rodríguez-Rubio, E., Schneider, W., \& Abarca del Río, R. (2003). On the seasonal circulation within the Panama Bight derived from satellite observations of wind, altimetry and sea surface temperature. Geophysical Research Letters, 30, 1410. DOI: 10.1029/ 2002GL016794

Rodríguez-Rubio, E., \& Stuardo, J. (2002). Variability of photosynthetic pigments in the Colombian Pacific Ocean and its relationship with the wind field using ADEOS-I data. Journal of Earth System Science, $111,227-236$.

Rodríguez-Sáenz, K. \& Morales-Ramírez, A. (2012). Composición y distribución del mesozooplancton en una zona de afloramiento costero (Bahía Culebra, Costa Rica) durante La Niña 1999 y el 2000. Revista de Biología Tropical, 60, 143-157.

Rykaczewski, R. R., \& Checkley, D. M. (2008). Influence of ocean winds on the pelagic ecosystem in upwelling regions. Proceedings of the National Academy of Sciences United States, 105, 1965-1970.

Smayda, T. J. (1966). A quantitative analysis of the phytoplankton of the Gulf of Panama III. General ecological conditions, and the phytoplankton dynamics at $8^{\circ} 45^{\prime} \mathrm{N}, 7^{\circ} 23^{\prime} \mathrm{W}$ from November 1954 to May 1957. Inter-American Tropical Tuna Commission Bulletin, 11, 355-612.

Stramma, L., Schmidtko, S., Levin, L. A., \& Johnson, G. C. (2010). Ocean oxygen minima expansions and their biological impacts. Deep Sea Research Part I: Oceanographic Research Papers, 57, 587-595.

UAESPNN. (1998). Plan de Manejo del Parque Nacional Natural Utría: Versión preliminar. Medellín, Colombia: Parques Nacionales Naturales de Colombia. 
UAESPNN. (2007). Plan de Manejo 2007-2011 del Parque Nacional Natural Utría, resumen ejecutivo. Medellín, Colombia: Parques Nacionales Naturales de Colombia.

Valencia, B., \& Giraldo, A. (2009). Hipéridos (Crustacea: Amphipoda) en el sector norte del Pacífico oriental tropical Colombiano. Latin American Journal of Aquatic Research, 37, 265-273.

Valencia, B., \& Giraldo, A. (2012). Structure of hyperiid amphipod assemblages on Isla Gorgona, eastern tropical Pacific off Colombia. Journal of the Marine Biological Association of the United Kingdom, 92, 1489-1499.
Vaquer-Sunyer, R., \& Duarte, C. M. (2008). Thresholds of hypoxia for marine biodiversity. Proceedings of the National Academy of Sciences United States, 105 , 15452-15457.

Willett, C. S., Leben, R. R., \& Lavín, M. F. (2006). Eddies and tropical instability waves in the eastern tropical Pacific: A review. Progress in Oceanography, 69, 218-238.

Zhang, J., Gilbert, D., Gooday, A., Levin, L., Naqvi, S. W. A., Middelburg, J. J., ... Oguz, T. (2010). Natural and human-induced hypoxia and consequences for coastal areas: synthesis and future development. Biogeosciences, 7, 1443-1467. 